\title{
MERAIH MASA DEPAN DENGAN MENINGKATKAN MOTIVASI DALAM HAL MANAJEMEN WAKTU DI RUMAH AMALIA
}

\author{
Wahyu Nurul Faroh*, Dien Mardiana Yuliati, Ibrahim Bali Pamungkas \\ Dosen Fakultas Ekonomi Universitas Pamulang \\ Email* : wahyunurulfaroh@gmail.com
}

\begin{abstract}
ABSTRAK
Tujuan ini bertujuan untuk mengetahui sejauh mana keberhasilan mengelolah waktu, memotivasi anak asuh dalam menjalani kehidupan, dan membuka paradigm berfikir anak-anak asuh terhadap keefektifan beraktifitas.

Teknik pendekatan dilakukan dengan metode penyuluhan dan simulasi secara oral dengan permainan edukatif dan tanya jawab.

Hasil kegiatan dapat meningkatkan kreatifitas dan kepercayaan diri dalam menjalani kehidupan tanpa ketergantungan dengan orang lain.

\section{Kata Kunci : Motivasi, Manajemen Waktu}

\section{PENDAHULUAN}

Seiring dengan perkembangan zaman, tuntutan terhadap anak untuk melakukan berbagai macam aktifitas semakin meningkat. Tak terkecuali anak-anak yatim-piatu juga mengalami hal yang sama. Oleh karena itu, mereka perlu dibekali dengan berbagai macam keterampilan untuk menghadapi tantangan masa depan. Salah satu keterampilan yang ingin difasilitasi oleh pengabdian masyarakat kali ini adalah tentang manajemen waktu.

Anak-anak yatim-piatu di lingkungan kita sebagian besar hidupnya dalam kesusahan dan kekurangan, karena kehilangan tulang punggung pencari nafkah dan figur orang tua dalam hidupnya. Mereka masih banyak yang sanggup dalam menuntut ilmu namun tidak bisa melanjutkan pendidikan ke jenjang yang lebih tinggi. Karena itu uluran tangan kita sebagai saudara sebangsa tentu sangatlah berarti, tidak hanya dengan simpati, tapi perlu adanya tindakan nyata dengan memberikan mereka penyuluhan tentang manajemen waktu.

Adalah sangat berdosa bagi kita apabila kita berdiam diri membiarkan masa depan mereka terbengkalai.Dengan diberikannya materi manajemen waktu ini, anak-anak yatim-piatu menjadi terbuka dan mampu mengatur aktifitas mereka sehingga menjadi lebih efektif dan bermanfaat. Tanpa melepas masa kanak-kanak
\end{abstract}


mereka, segala keterampilan yang mereka terima tetap dapat terlaksana. Perlu adanya dukungan dari pihak yayasan untuk menjalankan penyuluhan ini agar tersampaikan dengan maksimal.

Rumah Amalia adalah rumah belajar untuk anak yatim dan anak kaum dhuafa. Rumah Amalia didirikan sebagai bentuk kepedulian terhadap mereka yang terbatas dalam masalah ekonomi, perhatian dan bimbingan psikologis, akses terhadap pendidikan dan kurangnya ketersediaan bagi perkembangan minat dan bakat anak. Yayasan Rumah Amalia berada di Jalan Subagyo IV Blok II, No. 24 Komplek Peruri, Ciledug, Tangerang. Rumah Amalia juga fokus pada pendampingan dan pemulihan untuk anak-anak yang kehilangan orangtua, putus harapan dan kurang perhatian.

Dengan adanya materi ini tentang dampak diharapkan anak-anak tersebut mampu mengatur waktunya untuk menciptkan masa depan yang baik dan bermanfaat untuk orang lain. Oleh karena itu ,Perlu adanya dukungan dari pihak Yayasan untuk menjalankan pelatihan ini agar tersampaikan dengan maksimal.

Sasaran kegiatan Pengabdian Kepada Masyarakat (PKM) ini adalah dengan mengajak anak-anak asuh untuk mengikuti penyuluhan dengan tema "Meraih Masa Depan Dengan Meningkatkan Motivasi Dalam Hal Manajemen Waktu".

\section{PERUMUSAN MASALAH}

Berdasarkan latar belakang tersebut, kami dari Tim Program Pengabdian Masyarakat (PKM) Universitas Pamulang (UNPAM) yang berjumlah 10 dosen terpanggil untuk ikut serta membantu memberikan penyuluhan dan terkait materi "Meraih Masa Depan Dengan Meningkatkan Motivasi Dalam Hal Manajemen Waktu". yang beralamatkan J1. Subagyo IV Blok II, No. 24 Komplek Peruri, Ciledug, Tangerang, Banten. Membekali anak-anak untuk dapat memanfaatkan waktunya sebaik mungkin.

\section{TUJUAN}

Tujuan ini bertujuan untuk mengetahui sejauh mana keberhasilan mengelolah waktu, memotivasi anak asuh dalam menjalani kehidupan, dan membuka paradigm berfikir anak-anak asuh terhadap keefektifan beraktifitas.

\section{KEGIATAN}

Sasaran dari Program Pengabdian Masayarakat yang akan kami lakukan ini adalah anak-anak asuh Rumah Amalia, Jl. Subagyo IV Blok II, No. 24 Komplek Peruri, Ciledug, Tangerang, Banten. Jumlah Anak-anak asuh kurang lebih 90 orang. 
Adapun pelaksanaan dari kegiatan adalah sebagai berikut:

Waktu Pelaksanaan Kegiatan : Hari Jum'at, Sabtu, dan Minggu.

Tanggal

: 6-8 April 2018

Tempat

: Rumah Amalia, Jl. Subagyo IV Blok II, No. 24

Komplek Peruri, Ciledug, Tangerang, Banten.

\section{APLIKASI}

\section{A. Manajemen Waktu}

Manajemen waktu adalah suatu perencanaan, pengorganisasian, penggerakan dan controlling (pengawasan) produktivitas waktu. Sebab waktu menjadi salah satu sumber daya unjuk melakukan pekerjaan, dan merupakan sumber daya yang harus dikelola secara efektif dan efisien.

Efektifitas dapat terlihat dari tercapainya target atau tujuan manajemen waktu yang sudah ditetapkan sebelumnya. Dan kata efisien tidak lain mengandung 2 (dua) makna, yaitu makna pengurangan waktu yang ditentukan dan makna investasi waktu menggunakan waktu yang telah ada.

Atau definisi manajemen waktu yang lainnya yaitu suatu cara untuk mengatur dan memanfaatkan setiap bagian dari waktu untuk melakukan aktivitas tertentu yang sudah ditargetkan atau di tentukan dalam jangka waktu tertentu dan aktivitas tersebut haruslah diselesaikan.

Manajemen waktu yang baik yaitu dengan membuat data pekerjaan atau aktivitas dan menentukan skala dari setiap aktivitas tersebut. Perlu kita ketahui bahwa setiap aktivitas pasti semuanya penting akan tetapi dari data aktivitas pekerjaan tersebut pasti ada yang paling penting, misalnya seperti pekerjaan yang mendesak yang umumnya berkaitan dengan pekerjaan deadline. Letakkan-lah pekerjaan yang terpenting di daftar data paling atas untuk segera di kerjakan baru setelah itu di ikuti dengan daftar aktivitas pekerjaan yang lainnya.

Manajemen waktu ini dapat memberikan hasil yang lebih baik jika dilakukan dengan sungguh-sungguh tentunya dengan disiplin. Dan komitmen yang tinggi dari individu sagat dibutuhkan untuk mematuhi dan menjalankan manajeman waktu yang sudah di tentukan, misalnya oleh perusahaan atau tempat bekerja dalam menjalankan aktivitas sehari-hari.

\section{B. Pengertian Manajemen Waktu Menurut Ahli}

Menurut Atkinson - Manajemen waktu didefinisikan sebagai suatu jenis ketrampilan yang berkaitan dengan segala bentuk upaya dan tindakan seorang individu yang dilakukan secara terencana agar individu tersebut dapat memanfaatkan waktunya dengan sebaik - baiknya. 
Dan menurut Forsyth - Manajemen waktu adalah cara bagaimana membuat waktu menjadi terkendali sehingga menjamin terciptanya sebuah efektifitas dan efisiensi juga produktifitas.

\section{Prinsip Manajemen Waktu}

Untuk dapat mengatur atau me-manage waktu secara baik dan tepat diperlukan pemahaman mengenai prinsip dasar manajemen waktu supaya dapat berhasil dan memiliki daya guna, berikut di bawah ini yaitu prinsip dasar dari manajemen waktu yang harus di perhatikan:

1. Sediakanlah waktu untuk perencanaan dan untuk menetapkan prioritas.

2. Selesaikanlah pekerjaan atau tugas yang memiliki prioritas yang tinggi secepat mungkin dan selesaikan pekerjaan sebelum memulai pekerjaan yang lain.

3. Dan prioritaskan kembali tugas yang tersisa, berdasarkan informasi baru yang terkait.

\section{Pentingnya Manajemen Waktu}

Kenapa manajemen waktu sangatlah penting? karena waktu itu sangat berharga dan watu yang berlalu tak dapat di ulang lagi, inilah alasannya:

1. Dapat membantu kita untuk bekerja secara lebih efektif dan efesien dengan skala prioritas.

2. Dapat menjauhkan kita dari depresi, stress karena dengan menerapkan manajemen waktu kita dapat mengontrol setiap pekerjaan atau tugas dan tanggal waktunya.

3. Dan membuat kita lebih produktif.

\section{E. Manfaat Manajemen Waktu}

Sistem manajemen waktu yang sesuai dengan kebutuhan bisa membantu kita dalam menyelesaikan tugas pekerjaan dalam waktu yang lebih singkat. Apapun prioritasnya, mempelajari bagaimana cara mengatur waktu akan membantu kita dalam mencapai target atau tujuan yang sudah di tetapkan sebelumnya, inilah beberapa apa lasan mengapa kita harus memanage waktu:

1. Dapat membantu kita membuat prioritas. Seperti misalnya, manakah yang harus di dahulukan membayar uang sekolah atau membeli handphone baru.

2. Dapat mengurangi kecenderungan untuk menunda-nunda tugas atau pekerjaan.

3. Dapat membantu menghindari tabrakan waktu atau bentrok. Seperti misalnya, menghindari 2 (dua) kegiatan yang seharusnya tidak dilakukan secara bersamaan. 
4. Dan dapat membantu mengevaluasi perkembangan atau kemajuan kita dalam menyelesaikan tugas atau perkerjaan.

\section{STRATEGI}

Persiapan yang dilakukan adalah segala hal yang terkait dengan materi, bahan dan alat sesuai dengan tema secara baik. Hasil persiapan tersebut dimaksudkan agar materi tersampaikan dengan dan mudah dimengerti serta dipahami oleh anak-anak di Rumah Amalia.

\section{PENUTUP}

Pelaksanaan kegiatan Pengabdian Kepada Masyarakat oleh Lembaga Penelitian dan Pengabdian Masyarakat (LPPM) Universitas Pamulang yang dilakukan oleh dosen-dosen program studi Manajemen telah berjalan dengan lancar dan mendapat sambutan hangat dari tempat pelaksanaan kegiatan.

Harapan kami dengan pengabdian ini dapat membuka wawasan bagi anakanak, sehingga dapat membantu dan meningkatkan tingkat keilmuan dan keperibadian yang baik secara rohani dan jasmani sehat yang akan sangat bermanfaat dalam kehidupan mereka pada masa yang akan datang.

\section{DAFTAR PUSTAKA}

E. Atkinson, Philip. 1999. Manajemen Waktu Yang Efektif. Jakarta: Binarupa Aksara.

Forsyth, P. 2009. Jangan Sia-siakan Waktumu. (alih bahasa : Rifki). PT. Garailmu. Yogyakarta. Hal 25

Rumah Amalia, "Profil Organisasi”, 1 Oktober 2011.

https://www.indorelawan.org/organization/5662f6b029a350b3478b8cdf.

http://www.pengertianku.net/2015/05/pengertian-manajemen-waktu-dan-menurutpara-ahli.html 


\section{DOKUMENTASI FOTO KEGIATAN}

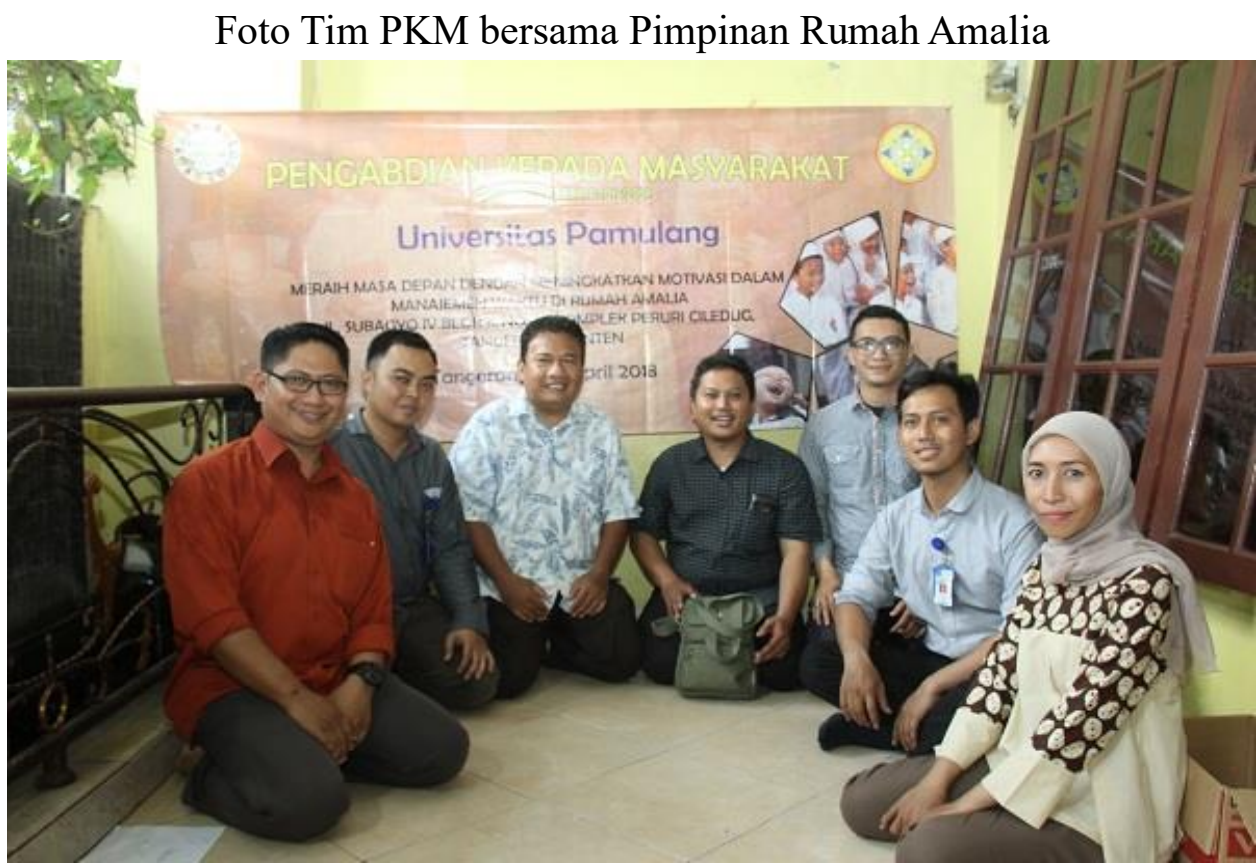

Tim PKM (Pengabdian Kepada Masyarakat)

Penyampaian Materi

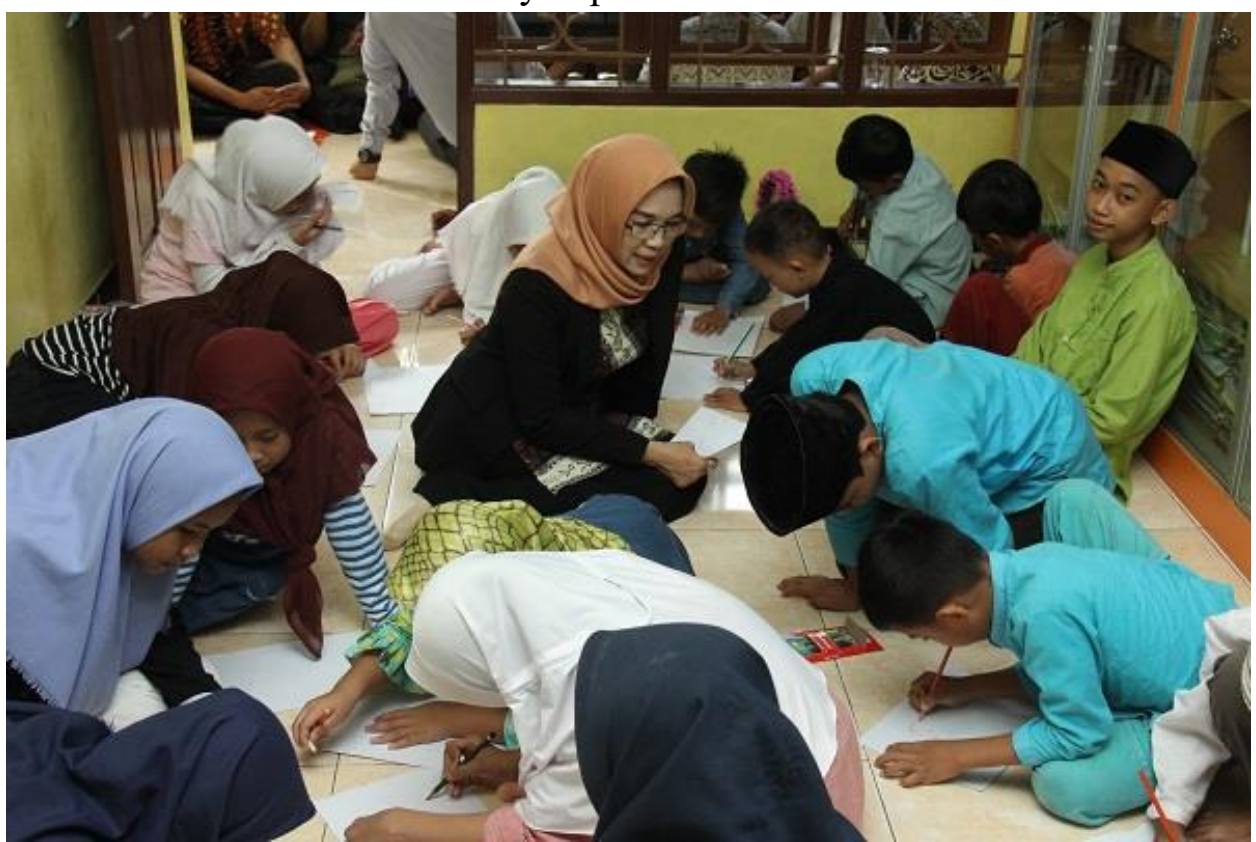

